Bangladesh J. Plant Taxon. 25(2): 257-271, 2018 (December)

(C) 2018 Bangladesh Association of Plant Taxonomists

\title{
TAXONOMIC REVISION OF THE GENUS CRINUM L. (LILIACEAE) OF BANGLADESH
}

\author{
Sumona Afroz, M. Oliur Rahman ${ }^{1}$ and Md. Abul Hassan \\ Department of Botany, University of Dhaka, Dhaka 1000, Bangladesh
}

Keywords: Crinum L.; Taxonomy; Revision; Amaryllidaceae; Bangladesh.

\begin{abstract}
The genus Crinum L. represented by eight species in Bangladesh is revised. The species occurring in Bangladesh are Crinum amabile Donn, C. amoenum Roxb., C. asiaticum L., C. defixum Ker-Gawl., C. jagus (Thomps.) Dandy, $C$. latifolium L., $C$. pratense Herb. and $C$. stenophyllum Baker. Each species is described with updated nomenclature, important synonyms, English and Bangla names, phenology, specimens examined, chromosome number, habitat, distribution, economic value and mode of propagation. A dichotomous bracketed key to the species and illustrations are also provided.
\end{abstract}

\section{Introduction}

The classification of the lilioid monocots has long been problematic (Chase et al., 2009). Some authors treated all lilioid monocots including the genus Crinum L. in one family, Liliaceae s.l. (Cronquist, 1981). Though the genus Crinum L. was formerly included in the family Liliaceae, the Angiosperm Phylogeny Group (APG) reevaluated the taxonomic position of this genus and placed it in the family Amaryllidaceae (APG III, 2009). Linnaeus established the genus Crinum in 1737 recognising four species, viz. Crinum latifolium, C. asiaticum, C. americanum and C. africanum (Nordal, 1977). The pantropical genus Crinum L. consists of about 112 species distributed in tropical Africa, America, Asia and Australia (Govaerts et al., 2012). The genus is most diverse in Africa, particularly sub-Saharan Africa. Biogeographical analyses place the origin of Crinum in southern Africa (Meerow et al., 2003; Kwembeya et al., 2007).

Crinum are perennial herbs with globose to ovoid subterranean bulbs. Herbert (1837) divided the genus into two sections on the basis of the degree to which the tepals are patent. Baker (1881) provided detailed insight into the genus Crinum and divided the genus into three subgenera based on floral characters, viz., Stenaster, Platyaster and Codonocrinum. The actinomorphic flowers with linear petals were placed in the subgenus Stenaster; actinomorphic flowers and lanceolate petals were included in the subgenus Platyaster, while the subgenus Codonocrinum is characterized by funnel-form, zygomorphic flowers and curved tubes. Later, Baker (1898) submerged Platyaster into subgenus Stenaster, which must be named subgenus Crinum as it contains the type species, $C$. americanum L. (Meerow et al., 2003). In order to resolve the mix-ups in nomenclature in Crinum several systematic studies have been carried out (Herbert, 1820; Baker, 1888, 1896; Hooker, 1892; Uphof, 1942; Verdoorn, 1973; Dassanayake, 2000). Though identification of Crinum species is straight forward, yet there is species complexity in many cases. In the recent past, many species of Crinum were placed under some other genera especially under Amaryllis, while many species belonging to other genera were transferred to Crinum (Hannibal and Williams, 1998). These snags were mainly due to inadequate research and misinterpretation or misidentifications of the plant specimens (Hannibal and Williams, 1998). Recently, Yakandawala and Samarakoon (2006) made an attempt to solve the taxonomic ambiguity on species limits of $C$. latifolium and C. zeylanicum.

${ }^{1}$ Corresponding author. Email: prof.oliurrahman@gmail.com; oliur.bot@du.ac.bd 
Members of Crinum are important for their ornamental, economical and medicinal values. Leaf extract is used for treatment for vomiting and for ear-aches. The bulbs are crushed and applied onto piles and abscesses to cause suppuration. In addition, the roasted bulbs are used as a rubefacient in rheumatism (Jayaweera, 1981). C. asiaticum possesses antimicrobial activities (Win, 2011). Phytochemical analysis has recently yielded a vast array of compounds, including more than 150 different alkaloids in the genus Crinum (Fennell and van Staden, 2001).

In Bangladesh, Crinum L. appears to be the largest genus in the family Liliaceae represented by eight species including both wild and cultivated. In the Indian sub-continent Hooker (1892) was the pioneer on the genus Crinum L. who recognised 19 species from this area of which 7 species were treated as doubtful or imperfectly known. Of these, four species were reported from the area of current Bangladesh. Later, Prain (1903) listed four Crinum species from the area of present Bangladesh. A very few cytological investigations on some Crinum species occurring in Bangladesh were made over last two decades. Alam et al. (1998) made a karyotype analysis in $C$. pretense and C. defixum with differential banding patterns. Later, Ahmed et al. (2004) studied flurescent banding in C. latifolium L., C. asiaticum L. and C. amoenum Roxb. Those studied were concentrated with orcein, CMA and DAPI rather than taxonomy of those species. Recently, Hassan (2007), and Afroz and Hassan (2008) documented six Crinum species occurring in Bangladesh with inadequate taxonomic description. There has been no detailed taxonomic studies on this genus in Bangladesh. Therefore, the present study aims to revise the genus Crinum L. in Bangladesh.

\section{Materials and Methods}

Plant samples of different Crinum L. species were collected from different parts of the country and planted in the Dhaka University Botanical Garden for further study. The collected plant specimens were critically studied and examined which were supplemented by the herbarium specimens housed at the Dhaka University Salarkhan Herbarium (DUSH) and Bangladesh National Herbarium (DACB). Identification of the Crinum species were confirmed in consultation with standard literature (Hooker, 1892; Karthikeyan et al., 1989; Raven and Zhengyi, 2000; Utech, 2002; Hassan, 2007) and matching with authentically identified herbarium specimens deposited in DUSH and DACB. Updated nomenclature is determined consulting The Plant List (2013), a working list of all plant species. Each species is described with updated nomenclature, important synonyms, English and Bangla names, flowering and fruiting period, specimens examined, chromosome number, habitat, distribution, economic value, and mode of propagation. A dichotomous bracketed key to the species and illustrations are also provided. The voucher specimens are deposited at DUSH.

\section{Results}

\section{Taxonomic treatment}

\section{Genus Crinum L.,}

Gen. Pl. ed. 1: 97 (1737); Sp. Pl.: 291 (1753); Benth. \& Hook. f., Gen. Pl. 3: 726 (1883); Bak., Handb. Amaryll. : 74 (1888); FI. Cap. 6: 198 (1896); FI. Trop. Afr. 7: 373 (1898); Phill., Gen. ed. 2: 203 (1951); Uphof in Herbertia 9: 63 (1942); Traub, the Genera of Amaryllidaceae : 60 (1963). Crinopsis Herb., Amaryll. : 270 (1837). Erigona Salisb., Gen. Pl. Fragm. : 115 (1866). Liriamus Rafin., Fl. Tell. 4: 23 (1836). Scadianus Rafin., Atl. Journ. : 164 (1833). Taenais Salisb., Gen. Pl. Fragm. : 115 (1856). Tanghekolli Adans. Fam. 2: 57 (1763).

Perennial herbs with tunicated bulbs, usually produced at the apex into a short or long false stem. Leaves long, lorate or ensiform, spirally arranged, sessile, with smooth or scabrous edges. 
Peduncle compressed, solid. Flowers large, fragrant, umbellate, short-pedicelled or sessile, spathes 2, lanceolate, scarious; bracteoles many, linear. Perianth funnel-shaped or almost salver-shaped, tube long, straight or incurved, perianth segments 6, linear-lanceolate or narrowly oblong, red to white, often striped, streaked, or overlaid with red abaxially. Stamens 6, adnate to the throat of the perianth tube; filaments free, filiform, declinate or diverging; anthers linear or oblong-linear, dorsifixed. Carpels 3, syncarpous. Ovary inferior, 3-celled, ovules few in each locule, biseriate; style long, filiform, more or less declinate; stigma small, sub-capitate. Fruit a capsule, sub-globose or obovoid, membranous or coriaceous, bursting irregularly. Seeds few, large, green, rounded or irregularly compressed.

\section{Key to the species of Crinum L. occurring in Bangladesh}

1. Perianth lobes linear 2

- Perianth lobes oblong or lanceolate 5

2. Umbels more than 15-flowered 3

- Umbels up to 15-flowered 4

3. Scape purplish, shorter than the leaves C. amabile

- Scape green, longer than the leaves C. asiaticum

4. Bulbs with a fusiform, stoloniferous base C. defixum

- Bulbs not stoloniferous C. stenophyllum

5. Perianth tube erect; stamens spreading 6

- Perianth tube upcurved; stamens declinate 7

6. Leaves acuminate, scabrous; perianth lobes shorter than the tube C. amoenum

- Leaves obtuse or sub-acute; perianth lobes longer than the tube C. pratense

7. Leaf margin scabrous; perianth vertically reddish on the back C. latifolium

- Leaf margin smooth; perianth white C. jagus

Crinum amabile Donn, Hort. Cantabring. ed. 6: 82 (1811). Crinum augustum Roxb., Fl. Ind. 2: 136 (1832).

(Figs $1 \&$ 7A-C).

English names: Purple Spider Lily, Pink Crinum lily, Giant Spider Lily, Tiger Lily.

Bangla name: Sukhdarshan.

A perennial herb with a large tunicated bulb, bulb c. $40 \times 12 \mathrm{~cm}$ with long stem; roots c. 15 $\mathrm{cm}$ long. Leaves long, c. 60-170 $\times 7-20 \mathrm{~cm}$, lorate, entire, acute, glabrous, green in colour. Scape solid, 60-130 cm long, purplish, 20-50 flowered umbel, green, glabrous, arise from the side of the stem. Flowers large, actinomorphic, bisexual, epigynous, purple, fragrant at night, pedicellate, pedicel c. $3.7 \mathrm{~cm}$ long. Spathes $2,15-25 \times 7.0-12.5 \mathrm{~cm}$, lanceolate, purplish-green or purple, bracteoles many, linear, c. $10.2 \times 0.5 \mathrm{~cm}$, white in colour. Perianth segments 6 , c. $17 \times 3 \mathrm{~cm}$, purple, lower parts forming a long, slightly curved tube, tube c. $13 \mathrm{~cm}$ long, purple. Stamens 6 , adnate to the throat of the perianth tube; filaments filiform, c. $9 \mathrm{~cm}$ long, purplish; anthers linear, 1.5-2.5 cm long, dorsifixed, yellow. Carpels 3, syncarpous; ovary inferior, c. $1.8 \mathrm{~cm}$ long, $3-$ celled, purple; style single, filiform, c. $22 \mathrm{~cm}$ long; stigma sub-capitate; placentation axile. Fruit not formed.

Flowering: Almost throughout the year.

Specimens examined: Dhaka: Dhaka University Botanical Garden, 15.11.2006, Sumona 3 (DUSH); Cantonment, Shaheed Anwar Girls College campus, 15.11.2006, 06.10.2016, Sumona 105 (DUSH). 


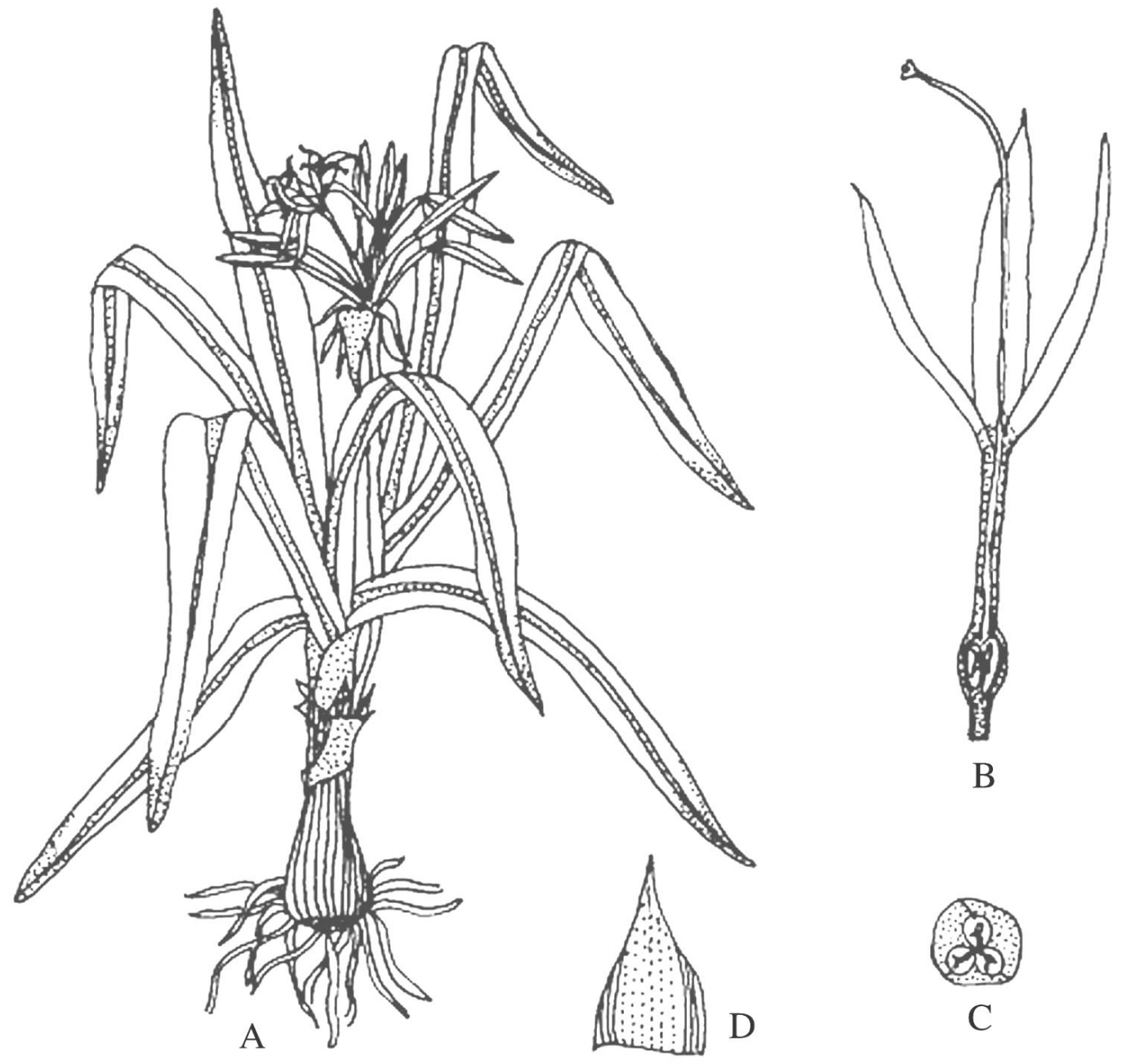

Fig. 1. Crinum amabile Donn: A. Habit $(\times 0.1)$; B. L.S. of a flower $(\times 0.2)$; C. T.S. of ovary $(\times 2)$; D. Bract $(\times 0.1)$.

Chromosome number: $2 \mathrm{n}=33$ (Ahmed et al., 2004).

Habitat: Cultivated in gardens.

Distribution: South Africa, Tropical regions of Asia. In Bangladesh, the species is cultivated in some private institutions and roadsides.

Economic value: Ornamental.

Propagation: By bulb separation. 
Crinum amoenum Roxb., Hort. Beng. : 23 (1814); Roxb., Fl. Ind. 2: 127 (1832); Hook. f., Fl. Brit. Ind. 6: 282 (1892); Prain, Beng. Pl. 2: 798 (1903); Hassan, Encycl. Flora \& Fauna of Bangladesh 11: 340 (2007). Crinum himalense Royle, Ill. Bot. Himal. Mts. (1839); Crinum verecundum Carey ex M. Roem., Fam. Nat. Syn. Monogr. : 75 (1847).

(Figs 2 \& 7D-F). English names: Himalayan Crinum, Tiger Lily.

Bangla name: Gang Kachu.

A bulbous perennial herb, bulb globose, 5.0-7.5 $\mathrm{cm}$ in diameter. Leaves $45-60 \times 2.5-4.0 \mathrm{~cm}$, bright-green, sub-erect, ensiform, tapering from the base to the tip, acuminate, margin subscabrous. Scape 30-60 cm long, rather slender, sub-cylindric, greenish-purple. Inflorescence of 612 flowered umbels; spathes 2, c. $5 \mathrm{~cm}$ long, lanceolate; bracteoles many. Flowers sub-sessile. Perianth tube green, 7.5-10.0 cm long, lobes $5.0-7.5 \mathrm{~cm}$ long, linear-lanceolate, longer than the filaments, white. Stamens 6; filaments red, c. $6 \mathrm{~cm}$ long, shorter than the perianth lobes; anthers oblong, dorsifixed. Carpels 3; ovary 3-celled, inferior, c. $1.6 \mathrm{~cm}$ long; placentation axile. Fruit a capsule. Seeds 1-5, irregularly round.

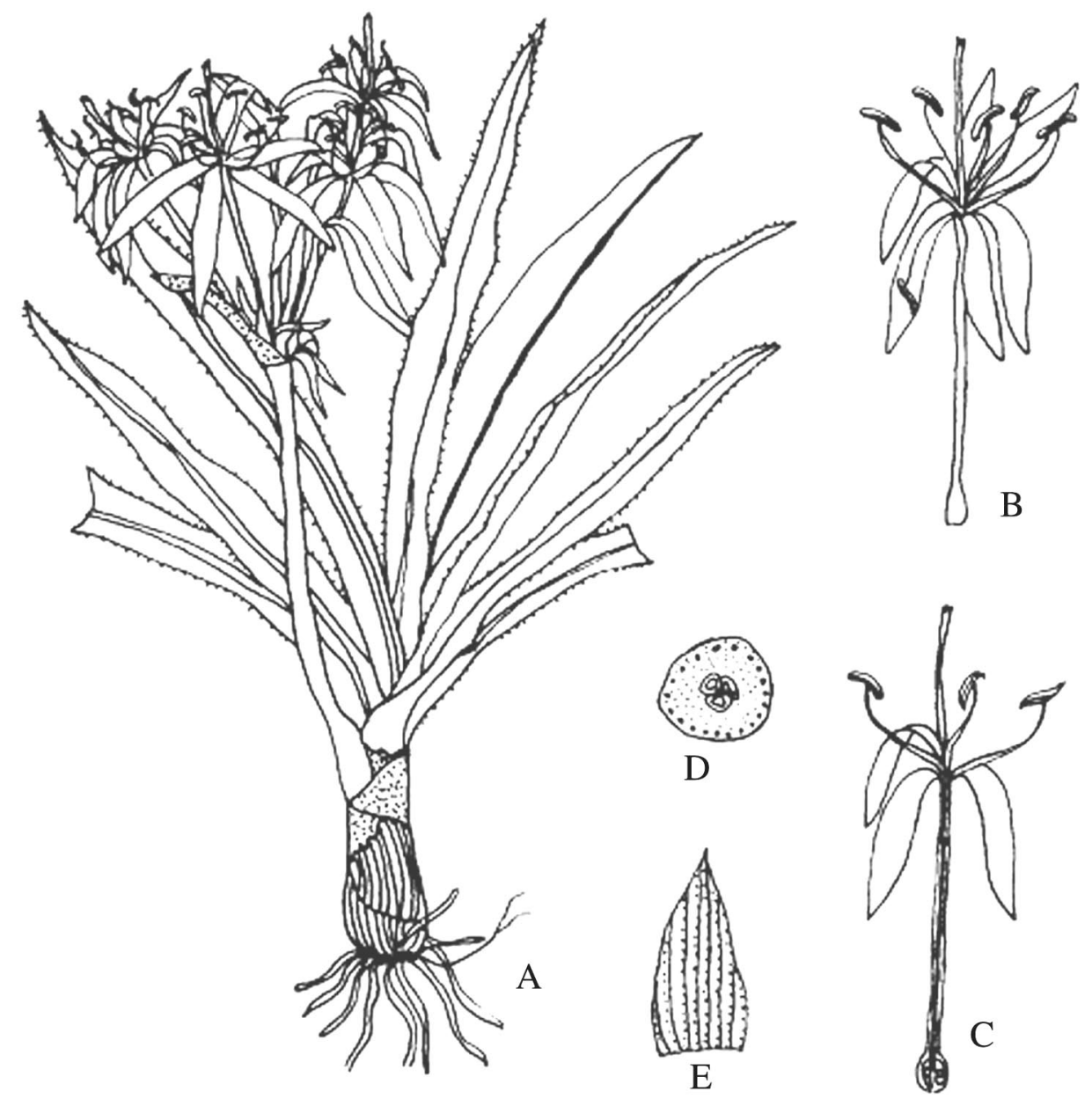

Fig. 2. Crinum amoenum Roxb.: A. Habit $(\times 0.2)$; B. Flower $(\times 0.3)$; C. L.S. of a flower $(\times 0.3)$; D. T.S. of ovary $(\times 3)$; E. Bract $(\times 0.5)$. 
Flowering and fruiting: May-August.

Specimens examined: Dhaka: Baldha Garden, 26.05.2007, Sumona 38 (DUSH); Dokkhin Middle Faidabad, 24.05.2007, Sumona 36 (DUSH). Patuakhali: Galachipa, Rangabali, 23.03.2006, M. Sultana 1208 (DUSH); Patuakhali Sadar, Laukathi, 15.05.2006, M. Sultana 1268 (DUSH). Chittagong: Chunati, Goalmara, 28.06.1997, Rahman et al. 663B (HCU). Cox's Bazar: Teknaf, Upazila Sadar, 25.05.2014, Sumona 88 (DUSH).

Chromosome number: $2 \mathrm{n}=18,22$ (Kumar and Subramaniam, 1986).

Habitat: In forests, plain lands and gardens.

Distribution: Tropical Himalayas, India (Sikkim and Khasia Hills), Nepal and Myanmar. In Bangladesh, it is distributed in Dhaka, Patuakhali, Sylhet, Cox's Bazar and Chittagong districts.

Economic value: Ornamental.

Propagation: By seeds and sucker formation.

Crinum asiaticum L., Sp. Pl.: 292 (1753); Hook. f., Fl. Brit. Ind. 6: 280 (1892); Prain, Beng. Pl. 2: 797 (1903); Utech, Fl. North Am. 26: 279 (2002); Hassan, Encycl. Flora \& Fauna of Bangladesh 11: 340 (2007). Amaryllis carnosa Herb. Ham. ex Hook. f., Fl. Brit. Ind. 6: 280 (1892). Crinum albiflorum Noronha, Verh. Batav. Genootsch. Kunst. 5(Art. 4): 12 (1790). Crinum angustifolium Herb. ex Steud., Nomencl. Bot. ed. 2, 1: 438 1(840). Crinum bancanum Kurz, Tijdschr. Nederl. Ind. 27: 231 (1864). Crinum bracteatum Willd., Sp. Pl., ed. 4. 2(1): 47 (1799). Crinum hornemannianum M. Roem., Fam. Nat. Syn. Monogr. : 71 (1847). Crinum macrocarpum Carey ex Kunth, Enum. Pl. 5: 553 (1850). Crinum plicatum Livings. ex Hook., Bot. Mag. 56: t. 2908 (1829). Crinum rumphii Merr., Interpr. Rumph. Herb. Amboin. : 141 (1917). Crinum sumatranum Roxb., Fl. Ind. 2: 131 (1832). Crinum umbellatum Carey ex Herb., Bot. Mag. 47: sub t. 2121, p. 7 (1820). Crinum woolliamsii L.S. Hannibal, Herbert. 43(1): 14 (1987). Crinum toxicarium Roxb., Fl. Ind. 2: 134 (1832).

(Figs 3 \& 7G-I).

English names: Poison Bulb, Giant Crinum Lily, Crinum Lily.

Bangla names: Bara Kanur, Nagdal, Kachori, Sukhdarshan, Gaerhonar-pata.

A perennial herb with a large tunicated bulb. Leaves long, $36-48 \times 3-5 \mathrm{~cm}$, lorate, margin entire, acute, wavy, glabrous, green in colour. Scape solid, 15-50 flowered umbels, green, glabrous. Flowers large, actinomorphic, bisexual, epigynous, white, fragrant at night, pedicellate; pedicel c. $3.3 \mathrm{~cm}$ long. Bracts 2, c. $6.5 \times 3.2 \mathrm{~cm}$, ovate-lanceolate, acute, greenish-white, bracteoles many, linear, white in colour. Perianth segments 6, c. $8 \times 1 \mathrm{~cm}$, white, lower parts forming a long, straight tube, tube erect, greenish, c. $7.5 \mathrm{~cm}$ long, equalling the linear lobes, lobes revolute. Stamens 6, adnate to the throat of the perianth tube; filaments filiform, c. $4.6 \mathrm{~cm}$ long, purplish in upper half and white in lower half; anthers linear, $1.5-2.5 \mathrm{~cm}$ long, dorsifixed, yellow. Carpels 3 , syncarpous, green; ovary inferior, c. $1.5 \mathrm{~cm}$ long, 3-celled, placentation axile; style single, filiform; stigma sub-capitate. Fruit a capsule, c. $3.0 \times 1.5 \mathrm{~cm}$, sub-globose, beaked, green, bursting irregularly. Seeds round, concave.

Flowering and fruiting: March-November.

Specimens examined: Dhaka: Dhaka University Botanical Garden, 08.08.2007, Sumona 43 (DUSH); ibid, 01.07.1968, Mozahar 155; 05.09.1994, M.M. Khan 89; Uttara, Sector No. 8, 12.07.2007, Sumona 41 (DUSH). Jhalakathi: Chankati, 03.03.1987, Huq \& Mia 6667 (DACB). Khulna: Sundarban, Manderbaria, 21.08.2002, S. Nasir Uddin N-1386(1); Sundarban, Kotka, 24.08.2010, Sumona 65; Kotka, 21.09.2011 Sumona 71 (DACB). Mymensingh: Bhaluka, 03.07.2001, M.S. Hossain 229; Ishwarganj, 05.07.2001, M.S. Hossain 261 (DACB). Patuakhali: Kalapara, Nilganj, 11.03.1999, M. Sultana 320 (DUSH); Patuakhali Sadar, Lohalia, 14.05.2005, 
M. Sultana 714 (DUSH); Kalapara, Gongamoti, 07.01.2006, M. Sultana 935 (DUSH); Kalapara, 08.08.2013, Sumona 81 (DUSH).

Chromosome number: $2 \mathrm{n}=22$ (Kumar and Subramaniam, 1986).

Habitat: Homesteads, coastal areas, and also cultivated in gardens.

Distribution: Throughout the tropical parts of India, Sri Lanka and Nepal. In Bangladesh, it is common in the Sundarbans and coastal areas of Chittagong, and also planted in gardens.
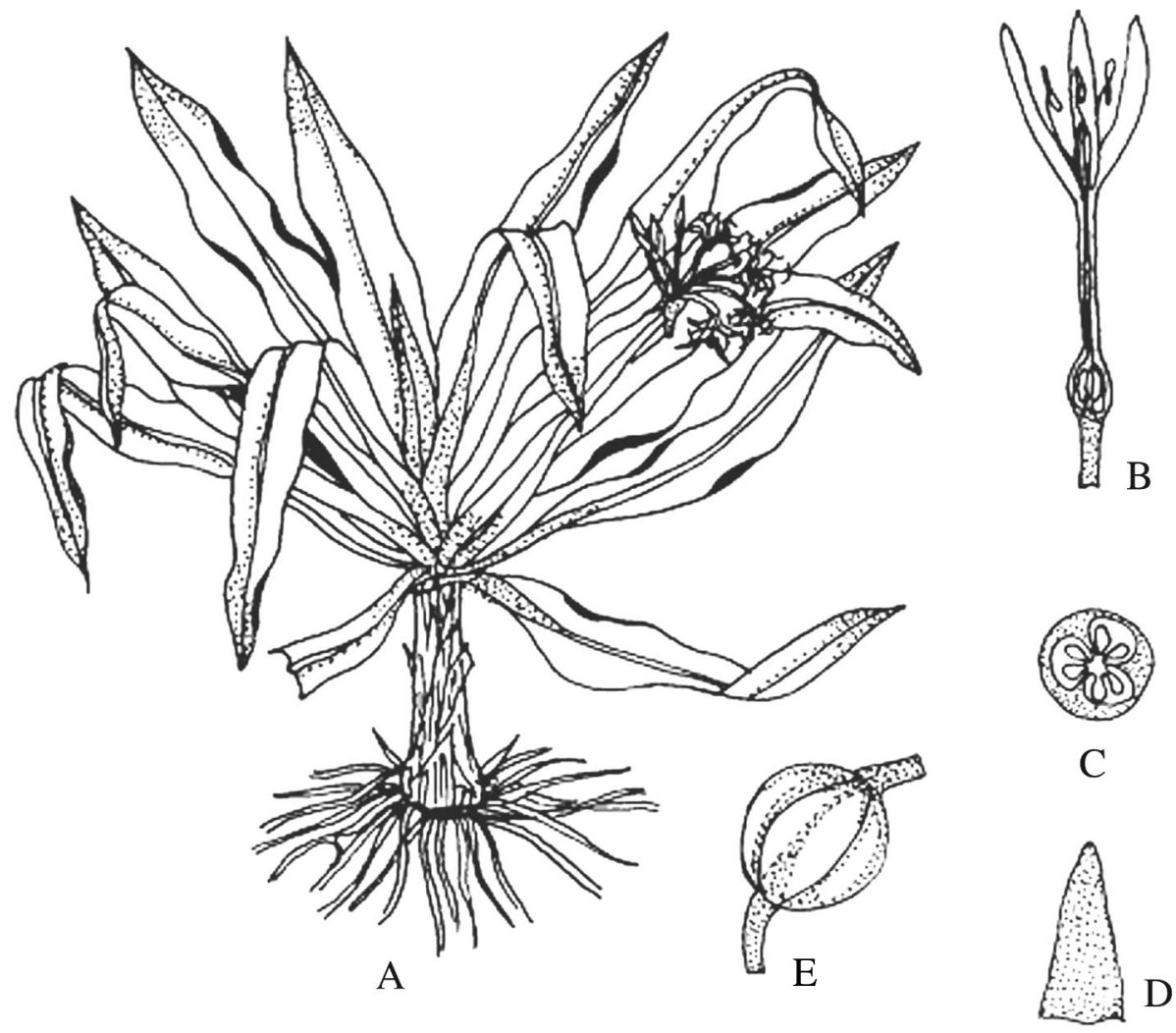

Fig. 3. Crinum asiaticum L.: A. Habit $(\times 0.1)$; B. L.S of a flower $(\times 0.4)$; C. T.S. of ovary $(\times 5)$; D. Bract $(\times 0.3)$; E. Fruit $(\times 1)$.

Economic value: Widely planted in the gardens for its beautiful flowers. The bulb contains the alkaloids lycorine, crinidine and hamayne (Ghani, 2003). The bitter bulb is tonic, laxative, expectorant, used in biliousness and strangury and other urinary complaints. Fresh root is emetic, nauseant and diaphoretic. Seeds are purgative, diuretic, emmenagogue and tonic. Leaves are expectorant, applied to skin diseases and to reduce inflammation (Sinha, 1996). Tuber is useful in bronchitis and diseases of the chest and lungs, gonorrhoea, night blindness and defective vision, disease of the spleen, urinary conceretions, lumbago, anuria, toothache and snake-bite (Kirtikar et al., 1935).

Ethnobotanical information: Leaf juice is used in ear-ache (Yadav and Bhandoria, 2013).

Propagation: By bulbs and seeds. 
Crinum defixum Ker-Gawl., Quart. Journ. Sci. 3: 105 (1817). Hook. f., Fl. Brit. Ind. 6: 281 (1892); Prain, Beng. Pl. 2: 798 (1903); Cooke, Fl. Pres. Bomb. 2: 749 (1908); Haines, Bot. Bih. Or.: 1108 (1924); Hassan, Encycl. Flora \& Fauna of Bangladesh 11: 341 (2007). Crinum asiaticum Roxb., Hort. Beng. : 23 (1814). Crinum viviparum (Lamk.) R. Ansari \& V.J. Nair, J. Econ. Taxon. Bot. 11(1): 205 (1988).

English names: Poison Bulb, Crinum Lily.

(Figs 4 \& 7J).

Bangla name: Sukhdarshan.

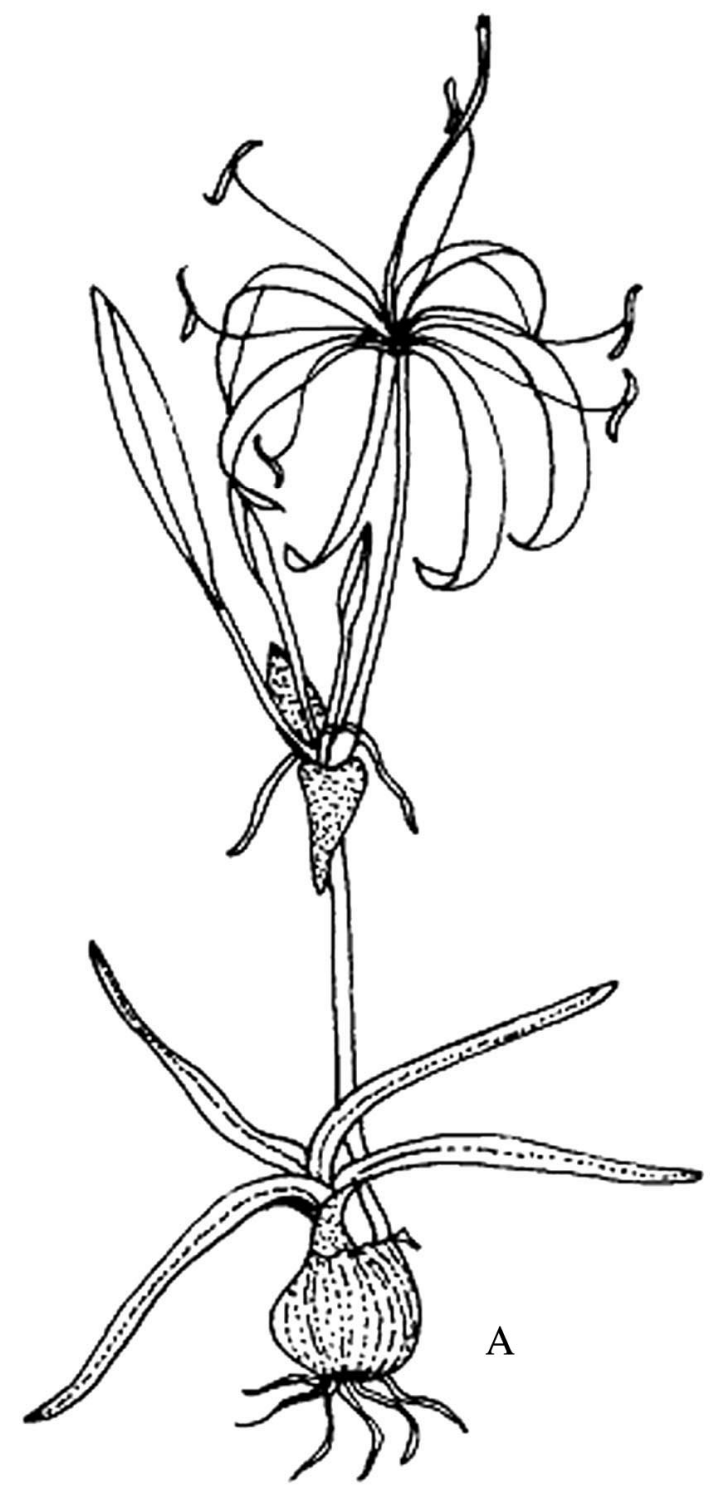

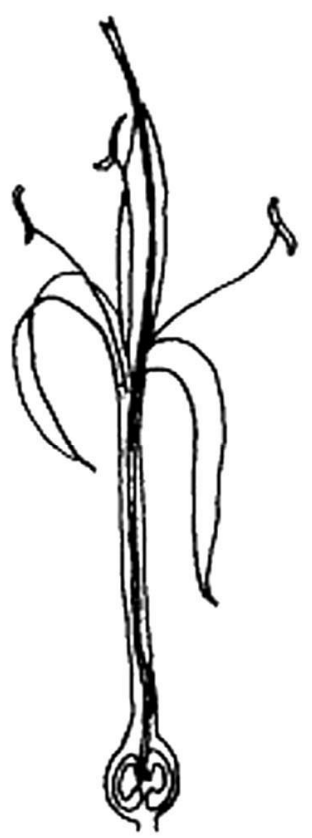

B

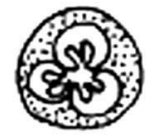

C

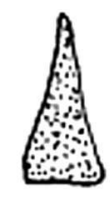

D

Fig. 4. Crinum defixum Ker-Gawl.: A. Habit $(\times 0.2)$; B. L.S. of a flower $(\times 0.4)$; C. T.S of ovary $(\times 0.3)$; D. Bract $(\times 0.2)$. 
Very stout bulbous herb, bulb with a fusiform stoloniferous base, neck cylindric. Leaves 30$80 \times 2-3 \mathrm{~cm}$, linear or linear-lanceolate, concave, smooth, entire, obtuse. Scape $35-50 \mathrm{~cm}$ long, usually shorter than the leaves, compressed, smooth; spathe 2-leaved, bracteoles filiform. Flowers in umbels, umbel usually 6-15 flowered, bisexual, large, shortly pedicellate. Perianth white, tube cylindric, $6.0-7.5 \mathrm{~cm}$ long, segments 6, linear, nearly as long as the tube. Stamens 6, adnate to the throat of the perianth tube, spreading, recurved; filaments white or pink, shorter than the perianth lobes; anthers oblong, brown, versatile. Carpels 3, syncarpous; ovary inferior, 3-celled; style erect, exserted; stigma simple. Fruit a capsule, ellipsoid, c $2.5 \mathrm{~cm}$ long, 1-2 seeded. Seeds large, rugose.

Flowering and fruiting: May-August.

Specimens examined: Dhaka: Dhaka University Botanical Garden (originally collected from Char Kukri Mukri), 05.07.2017, Sumona 110 (DUSH); Savar: Jahangirnagar University campus, 30.04.2015, Sumona 94 (DUSH). Patuakhali: Bhupal, Kalaiya, 13.03.1973, M. S. Khan K-2843 (DACB); Patuakhali Sadar, Lohalia, 18.11.2004, M. Sultana 462 (DUSH); Mirzaganj, Subidkhali, 20.11.2004, M. Sultana 565 (DUSH); Galachipa, Basbunia, 01.03.2005, M. Sultana 619 (DUSH); Galachipa, Panpotti, 18.12.2010, M. Sultana 1860 (DUSH).

Chromosome number: $2 \mathrm{n}=22$ (Alam et al., 1998); 50, 60 (Kumar and Subramaniam, 1986).

Habitat: Swampy river banks and gardens where it is commonly cultivated.

Distribution: Throughout tropical India and Sri Lanka. In Bangladesh, it is well represented in forests and many gardens.

Economic value: Commonly cultivated in the gardens for its beautiful large fragrant flowers. Bulb is nauseous, emollient, emetic and diaphoretic. The plant is toxic to cattle (Sinha, 1996). Bulb and stolon are administered in the treatment of burns and carbuncle. In otitis a few drops of juice of leaves are instilled into the ear. In Rema Kalenga area of Moulvi Bazar district bulbs are used for the treatment of stomach complaints of cow (Yusuf et al., 2009).

Propagation: By bulbs.

Crinum jagus (Thomps.) Dandy, Journ. Bot. Lond. 77: 64 (1939). Amaryllis jagus Thomps., Bot. Displ. : t. 6 (1798); Crinum giganteum Andr., Bot. Rep. : t. 169 (1810).

(Figs 5 \& 7K).

English name: Giant Crinum.

Bangla name: Sukhdarshan.

A bulbous perennial herb, bulb globose, $12.5-15.0 \mathrm{~cm}$ in diameter with $\mathrm{c} .7 \mathrm{~cm}$ long neck. Leaves many, 60-90 $\times 7-12 \mathrm{~cm}$, lorate or lanceolate, margin entire, wavy, acute or obtuse. Scape $30-90 \mathrm{~cm}$ long, green; spathes 2 , greenish-white, ovate-lanceolate, c. $9.7 \times 5.9 \mathrm{~cm}$, obtuse; bracteoles 4-8, linear-lanceolate, c. $8.0 \times 0.7 \mathrm{~cm}$, greenish-white. Inflorescence of 4-8 flowered umbels, short-pedicelled or sessile. Perianth segments 6 , c. $11.5 \times 4.0 \mathrm{~cm}$, ovate-lanceolate, fragrant, white, lobes as long as or shorter than the tube, tube c. $19 \mathrm{~cm}$ long, green. Stamens 6; filaments adnate to the throat of the perianth tube, $6-8 \mathrm{~cm}$ long, shorter than the perianth lobes, curved, white; anthers oblong, c. $1.5 \times 0.2 \mathrm{~cm}$, dorsifixed, versatile, spiral after bursting. Carpels 3 , syncarpous; ovary 3-celled, inferior, c. $2.5 \times 1.5 \mathrm{~cm}$; placentation axile; style with stigma c. $9.5 \mathrm{~cm}$ long, green. Fruit a sub-globose capsule. Seeds not found.

Flowering and fruiting: April-July.

Specimens examined: Dhaka: Dhaka University campus, Science Library, 03.05.2007, Sumona 25 (DUSH); Near Charukala Institute, 26.05.2007, Sumona 39 (DUSH); Dhaka University Btanical Garden (originally collected from Char Kukri Mukri), 10.05.2017, Sumona 106 (DUSH).

Chromosome number: $2 \mathrm{n}=33$ (Kumar and Subramaniam, 1986). 
Habitat: Soil rich in organic matter.

Distribution: Native to tropical Africa. Found in Sri Lanka, India, Myanmar, and Malaysia. In Bangladesh, it is found to be grown in different gardens.

Economic value: Cultivated in the gardens for its large beautiful flowers.

Ethnobotanical information: Crushed and roasted bulbs are used in rheumatism. Leaf juice is used in ear-ache (Sinha, 1996).

Propagation: By bulbs.

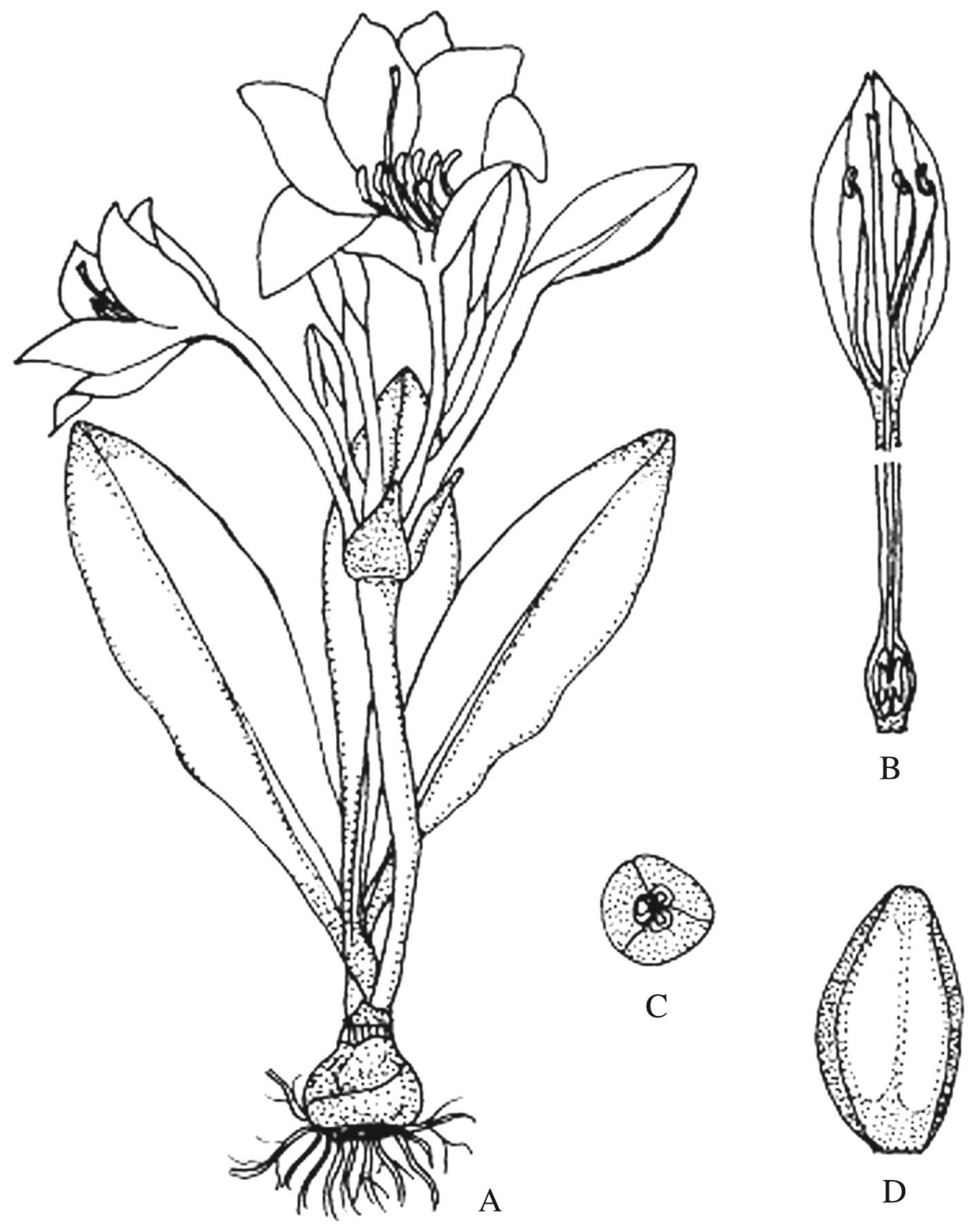

Fig. 5. Crinum jagus (Thomps.) Dandy: A. Habit $(\times 0.1)$; B. L.S. of a flower $(\times 0.1)$; C. T.S. of ovary $(\times 2)$; D. Bract $(\times 0.1)$. 
Crinum latifolium L., Sp. Pl.: 291 (1753); Hook. f., Fl. Brit. Ind. 6: 283 (1892); Prain, Beng. Pl. 2: 798 (1903); Raven and Zhengyi, Fl. China 24: 265 (2000); Hassan, Encycl. Flora \& Fauna of Bangladesh 11: 341 (2007). Crinum ornatum Herb., Amaryll. : 262 (1837). Crinum moluccanum Roxb., Fl. Ind. 2: 140 (1859). Crinum zeylanicum L., Syst. ed. 12 (1767).

(Figs 6 \& 7L).

English name: Pink Striped Trumpet Lily.

Bangla name: Sukhdarshan.

A bulbous perennial herb, bulb globose, $12.5-15.0 \mathrm{~cm}$ in diameter with a short neck. Leaves many, 60-90×7-12 cm, lorate, margin sub-scabrid. Scape 60-90 cm long, greenish-purple or yellowish-green; spathes 2, reddish-green or purple, lanceolate. Inflorescence of 6-12 flowered umbels, short-pedicelled. Perianth segments 6, c. $12.2 \times 3.0 \mathrm{~cm}$, perianth tube curved, c. $7 \mathrm{~cm} \mathrm{long}$, lobes $7-15 \mathrm{~cm}$ long, as long as or shorter than the tube, elliptic-oblong or elliptic-lanceolate, fragrant, white, more or less streaked or tinged with red towards the centre, sometimes red-purple, nearly all over the back. Stamens 6, declinate; filaments adnate to the throat of the perianth tube, 6-8 $\mathrm{cm}$ long, shorter than the perianth lobes; anthers oblong, 1.3-2.0 $\mathrm{cm}$ long, grey, dorsifixed, versatile. Carpels 3 , syncarpous; ovary inferior, 3 -celled, c. $1 \mathrm{~cm}$ long; placentation axile. Fruit a sub-globose capsule, c. $4.5 \times 3.0 \mathrm{~cm}$, pinkish-maroon.

Flowering and fruiting: May-September.

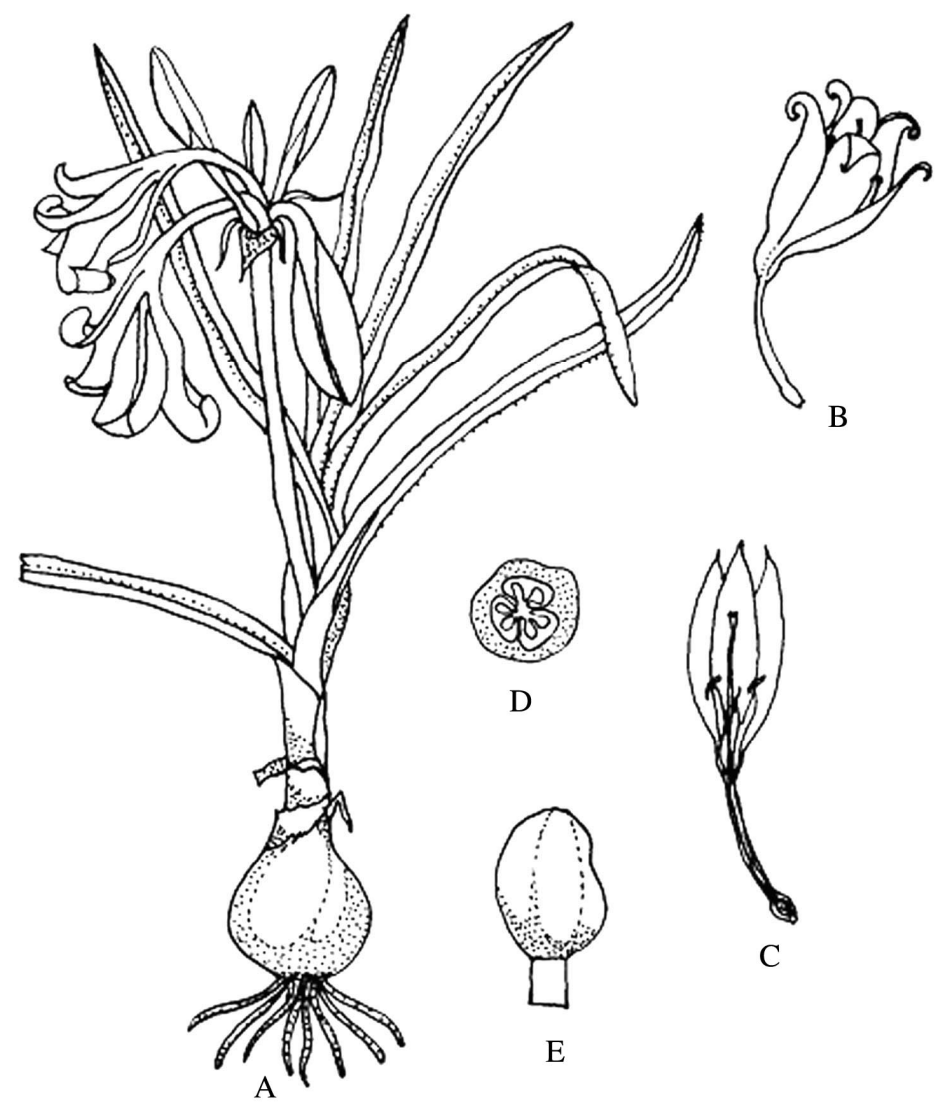

Fig. 6. Crinum latifolium L.: A. Habit $(\times 0.1)$; B. Flower $(\times 0.1)$; C. L.S. of a flower $(\times 0.1)$; D. T.S. of ovary $(\times 2)$; E. Fruit $(\times 0.4)$. 
Specimens examined: Dhaka: Dhaka University Botanic Garden, 28.04.2007, Sumona 24 (DUSH); Dhaka University Campus, Science Library, 19.09.2007, Sumona 44 (DUSH); ibid. 20.08.2012, Sumona 74 (DUSH).

Chromosome number: $2 \mathrm{n}=22,33$ (Kumar and Subramaniam, 1986).

Habitat: Soil rich in organic matter.

Distribution: Native to tropical Asia. Distributed throughout Sri Lanka, India and Myanmar, also in Malaysia and Africa. In Bangladesh, it is cultivated in different gardens.

Economic value: The bulbs are extremely acidic. In India, when roasted, they are used as rubifacient, or crushed on piles and abscesses to cause suppuration. Leaf juice is used for ear-ache (van Valkenburg and Bunyapraphatsara, 2002). Crushed and roasted bulbs are used in rheumatism (Sinha, 1996).

Ethnobotanical information: In some parts of India bulbs are used in traditional medicine (Kehimkar, 2000).

Propagation: By bulbs.

Crinum pratense Herb., Amaryll.: 256 (1837). Hook. f., Fl. Brit. Ind. 6: 282 (1892); Prain, Beng. Pl. 2: 798 (1903); Cooke, Fl. Pres. Bomb. : 750 (1908); Hassan, Encycl. Flora \& Fauna of Bangladesh 11: 342 (2007). Crinum longifolium Roxb., Fl. Ind. 2: 130 (1832). Crinum lorifolium Roxb. ex Ker-Gawl., J. Sci. Arts 3(5): 110 (1817).

Bangla names: Sukhdarshan, Bon Peyaj.

A bulbous perennial herb, bulb ovoid or spherical, $10-13 \mathrm{~cm}$ in diameter, neck 5-7 cm across. Leaves $45-90 \mathrm{~cm}$ long, linear, channelled, sub-erect or declinate, entire, obtuse. Scape c. $30 \mathrm{~cm}$ or more long, compressed, decumbent; spathe 5.0-7.5 cm long, deltoid-lanceolate. Flowers in umbels, white, fragrant, shortly pedicellate, bisexual, epigynous. Perianth tube $7.5-10.0 \mathrm{~cm} \mathrm{long}$, perianth lobes lanceolate. Stamens 6, adnate to the throat of the perianth tube; filaments filiform, red; anthers oblong, dorsifixed, bursting longitudinally. Carpels 3, syncarpous; ovary inferior, 3celled; style single; stigma simple. Fruit a capsule.

Flowering and fruiting: May-August.

Specimen examidned: Dhaka: Dhaka University Botanic Garden (originally collected from Chanbari beat of Rema-Kalenga Wildlife Sanctuary in Habiganj), 01.06.2000, Zashim Uddin 835 (DACB).

Chromosome number: $2 \mathrm{n}=22$ (Alam et al., 1998).

Habitat: Plain lands, also on the bank of channel (Uddin and Hassan, 2004).

Distribution: Plains of India and Myanmar. In Bangladesh, it is found both in wild and planted in household gardens.

Economic value: Used as an ornamental herb.

Propagation: By bulbs.

Crinum stenophyllum Baker, Gard. Chron. 1: 786 (1881); Handb. Amaryl. : 75 (1888); Hook. f., Fl. Brit. Ind. 6: 281 (1892); Hassan, Encycl. Flora \& Fauna of Bangladesh 11: 342 (2007).

Herbs. Leaves $90 \times 0.6-1.0 \mathrm{~cm}$, linear, flaccid. Scape very slender, 2-edged. Inflorescence umbel, 4-6 flowered. Spathe c. $5 \mathrm{~cm}$ long, lanceolate. Pedicel c. $0.6 \mathrm{~cm}$ long. Perianth tube 7-10 $\mathrm{cm}$ long, very slender, lobes half as long or longer.

Specimen examined: No specimen was examined because of unavailability in nature and in any herbarium of Bangladesh. 
Distribution: India, Bangladesh and Myanmar.

Notes: J.D. Hooker reported this species from Sylhet district in 1892. Since then there has been no further report of its occurrence from anywhere Bangladesh and no specimen available at any herbarium of Bangladesh. Hence, the species is presumed to be extinct in Bangladesh.
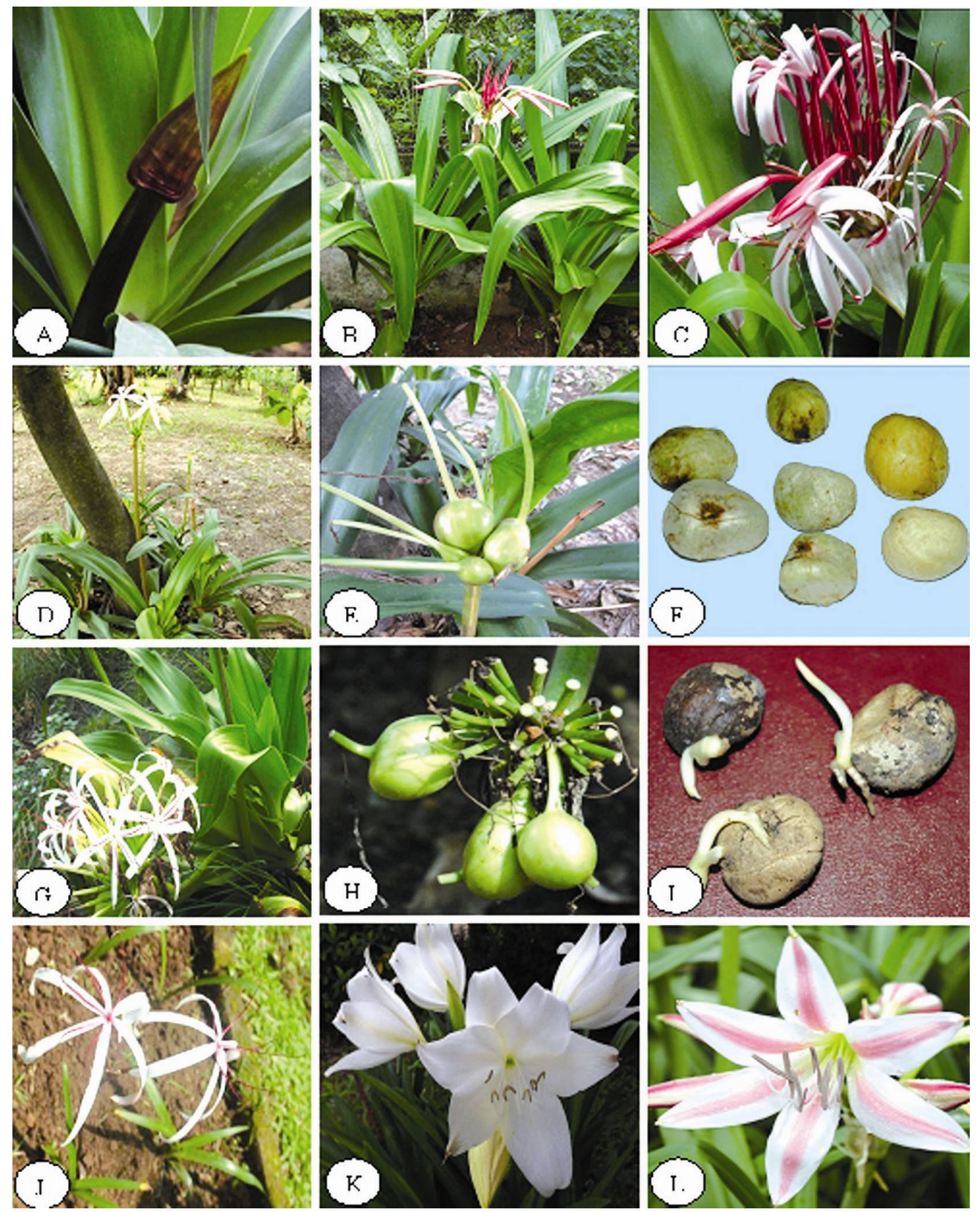

Fig. 7. Photographs of Crinum L. species: A-C. Crinum amabile Donn; D-F. C. amoenum Roxb.; G-I. C. asiaticum L.; J. C. defixum Ker-Gawl.; K. C. jagus (Thomps.) Dandy; L. C. latifolium L. 


\section{Acknowledgement}

The first author is thankful to Prime Minister's Office for financial support under 'Prime Minister's Research and Higher Education Supporting Fund' for carrying out the study.

\section{References}

APG III. 2009. An update of the Angiosperm Phylogeny Group classification for the orders and families of flowering plants: APG III. Bot. J. Linn. Soc. 161: 105-121.

Afroz, S. and Hassan, M.A. 2008. Systematic studies in the family Liliaceae from Bangladesh. Bangladesh J. Plant Taxon. 15(2): 115-128.

Ahmed, L., Begum, R., Noor, S.S., Zaman, M.A. and Alam, S.S. 2004. Reversible flurescent chromosome banding in three Crinum spp. (Amaryllidaceae). Cytologia 69(1): 69-74.

Alam, S.S., Sharmin, S.A., Sarker, R.H. and Zaman, M.A. 1998. Karyotype analysis with differential bandings in Crinum pratense and C. defixum. Cytologia 63: 223-227.

Baker, J.G. 1881. Synopsis of known species of Crinum. I. Gard. Chron. 15: 763.

Baker, J.G. 1888. Handbook of the Amaryllidaceae. London: George Bell and Sons, London, pp. 74-95.

Baker, J.G. 1896. Amaryllidaceae. Flora Capensis. L. Reeve and Co. Ltd., Kent, England. 6: 171-246.

Baker, J.G. 1898. Amaryllidaceae. In: Thiselton-Dyer, W.T. (Ed.), Flora of Tropical Africa, Vol. 7. London: L. Reeve, pp. 376-413.

Chase, M.W., Reveal, J.L. and Fay, M.F. 2009. A subfamilial classification for the expanded asparagalean families Amaryllidaceae, Asparagaceae and Xanthorrhoeaceae Bot. J. Linn. Soc. 161: 132-136.

Cronquist, A. 1981. An Integrated System of Classification of Flowering Plants. Columbia University Press, New York.

Dassanayake, M.D. 2000. Amaryllidaceae. In: Dassanayake, M.D. and Clayton, W.D. (Eds), A Revised Handbook to the Flora of Ceylon. Oxford and IBH Publishing Co. Pvt. Ltd., New Delhi \& Calcutta. 14: $18-20$.

Fennell, C.W. and van Staden, J. 2001. Crinum species in traditional and modern medicine. J. Ethnopharmacol. 78: 15-26.

Ghani, A. 2003. Medicinal Plants of Bangladesh. Asiatic Society of Bangladesh, Dhaka, pp. 1-460.

Govaerts, R., Snijman, D.A., Marcucci, R., Silverstone-Sopkin, P.A. and Brullo, S. 2012. World checklist of Amaryllidaceae. Facilitated by the Royal Botanic Gardens, Kew. 〈http://apps.kew.org/wcsp〉.

Hannibal, L.S. and Williams, A. 1998. The Genus Crinum (Amaryllidaceae). 〈http://www.crinum.org>. Retrieved on 15 July 2018

Hassan, M.A. 2007. Liliaceae. In: Siddique, K.U., Islam, M.A., Ahmed, Z.U., Begum, Z.N.T., Hassan, M.A., Khondker, M, Rahman, M.M., Kabir, S.M.H., Ahmad, A.T.A., Rahman, A.K.A. and Haque, E.U. (Eds), Encyclopedia of Flora and Fauna of Bangladesh. Vol. 11. Angiosperms: Monocotyledons (AgavaceaeNajadaceae). Asiatic Society of Bangladesh, Dhaka, pp. 339-343.

Herbert, W.M. 1820. Specierum Enumeratio ex pt. Crinum broussonetii. Botanical Magazine 47: 4-8.

Herbert, W. 1837. Amaryllidaceae. James Ridgway \& Sons, Piccadilly, London, pp. 242-275.

Hooker, J.D. 1892. The Flora of British India. Vol. 6. L. Reeve and Co. Ltd., Kent, England, pp. 280-284.

Jayaweera, D.M.A. 1981. Medicinal Plants used in Ceylon. Part I. National Science Council of Sri Lanka, Colombo, pp. 1-61.

Karthikeyan, S., Jain, S.K., Nayar, M.P. and Sanjappa, M. 1989. Flora of India. Ser. 4. Botanical Survey of India, Pune, India, pp. 1-102.

Kehimkar, I. 2000. Common Indian Wild Flowers. Bombay Natural History Society. Oxford University Press, Calcutta, India, pp. 1-141.

Kirtikar, K.R., Basu, B.D. and An, I.C.S. 1935 (reprint ed. 1994). Indian Medicinal Plants (Second edition). Vol. 4. Bishen Singh Mahendra Pal Singh, Dehra Dun, India, pp. 2465-2528. 
Kumar, V. and Subramaniam, B. 1986. Chromosome Atlas of Flowering Plants of the Indian Subcontinent. Vol. II, Botanical Survey of India, Calcutta, India, pp. 1-464.

Kwembeya, E.G., Bjora, C.S., Stedje, B. and Nordal, I. 2007. Phylogenetic relationship in the genus Crinum (Amaryllidaceae) with emphasis on tropical African species: evidence from trnL-F and nuclear ITS DNA sequence data. Taxon 56: 801-810.

Meerow, A.W., Lehmiller, D.J. and Clayton, J.R. 2003. Phylogeny and biogeography of Crinum L. (Amaryllidaceae) inferred from nuclear and limited plastid non-coding DNA sequences. Bot. J. Linn. Soc. 141: 349-363.

Nordal, I. 1977. Revision of the East African taxa of the genus Crinum (Amaryllidaceae). Norwegian J. Bot. 24: $179-194$.

Prain, D. 1903. Bengal Plants, Vol. 2. Botanical Survey of India, Calcutta, pp. 797-798.

Raven, P. and Zhengyi, W. (Eds) 2000. Flora of China, Vol. 24. Flagillariaceae through Marantaceae. Science Press, Beijing, and Missouri Botanical Garden Press, St. Louis, pp. 1-431.

Sinha, S.C. 1996. Medicinal Plants of Manipur. Mass and Sinha, Manipur Cultural Integration Conference Palace Compound, Imphal, India, pp. 1-238.

The Plant List 2013. Version 1.1. Published on the Internet; http://www.theplantlist.org/ (Accessed on 30 July 2018).

Uddin, M.Z. and Hassan, M.A. 2004. Flora of Rema-Kalenga Wildlife Sanctuary. IUCN-Bangladesh Country Office, Dhaka, Bangladesh, pp. 1-122.

Uphof, J.C.T. 1942. A review of the species of Crinum. Herbertia 9: 63-84.

Utech, F.H. 2002. Flora of North America: North of Mexico. Vol. 26. Flora of North America Editorial Committee (Eds), Oxford University Press, New York, USA, pp. 1-752.

van Valkenburg, J.L.C.H. and Bunyapraphatsara, N. (Eds). 2002. Plant Resources of South-East Asia. No. 12. Medicinal and Poisonous Plants 2. Backhuys Publishers, Leiden, the Netherlands, pp. 1-782.

Verdoorn, C. 1973. The Genus Crinum in Southern Africa. Bolhalia 11(1\&2): 27-52.

Win, Z.Z. 2011. Phytochemical investigation and antimicrobial activities of the leaves of Crinum asiaticum L. Univ. Res. J. 4(1): 123-137.

Yadav, S.S. and Bhandoria, M.S. 2013. Ethnobotanical exploration in Mahendergarh district of Haryana (India). J. Med. Plants Res. 7(18): 1263-1671.

Yakandawala, D.M.D. and Samarakoon, T.M. 2006. An empirical study on the taxonomy of Crinum zeylanicum (L.) L. and Crinum latifolium L. (Amaryllidaceae) occurring in Sri Lanka. Cey. J. Sci. (Biol. Sci.) 35(1): 53-72.

Yusuf, M., Chowdhury, J.U., Haque, M.N. and Begum, J. 2009. Medicinal Plants of Bangladesh. Bangladesh Council of Scientific and Industrial Research, Chittagong, Bangladesh, pp. 1-794. 